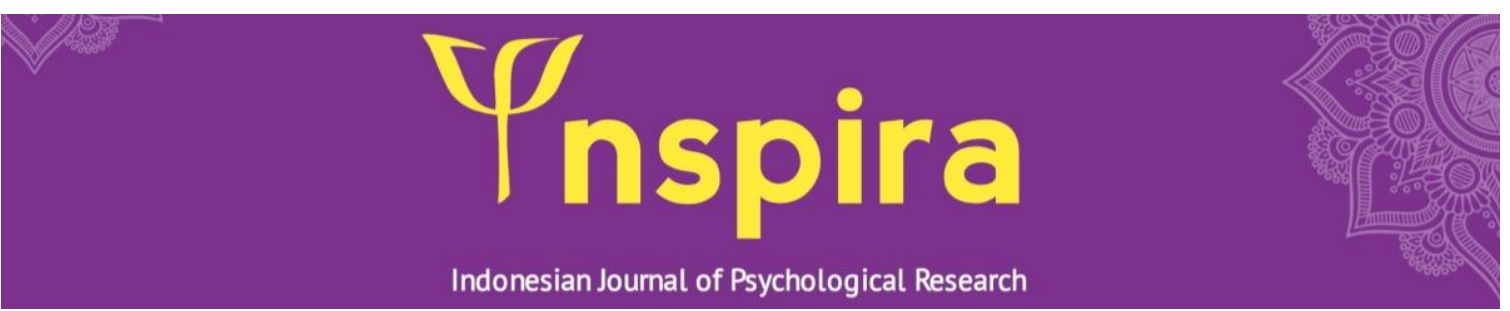

\title{
Predicting students' aggressive behavior by coping mechanisms and interpersonal communication
}

Eva Yulina ${ }^{1 凶}$, Asih Menanti ${ }^{2}$, Suryani Hardjo ${ }^{3}$

1,3 Department of Psychology, Universitas Medan Area, North Sumatera, Indonesia;

${ }^{2}$ Department of Counseling, Universitas Negeri Medan, North Sumatera, Indonesia;

\section{$\bowtie$ Corresponding author:}

Eva Yulina (email: eva.siregar87@gmail.com)

\begin{abstract}
This study aims to determine the relationship between coping mechanisms and interpersonal communication with aggressive behavior of students of the Department of Automotive at SMK PAB 12 Saentis. This type of research is quantitative by involving 93 students as a sample taken with total sampling techniques with the first screening of aggressive behavior tendencies. This study used 3 (three) coping mechanism scales, interpersonal communication scales, and aggressive behavior scales to obtain data analyzed using multiple regression analysis. The results showed a negative relationship between coping mechanisms and interpersonal communication with students' aggressive behavior simultaneously and partially. Coping mechanisms and interpersonal communication can predict the emergence of aggressive behavior of students by $52.8 \%$.
\end{abstract}

\section{Article History: \\ Received: April 1, 2021 \\ Revised: May 5, 2021 \\ Accepted: June 29, 2021 \\ Published: June 30, 2021}

$\begin{array}{lr}\text { Keyword: } & \\ \text { adolescents; } & \text { coping } \\ \text { mechanism; interpersonal } \\ \text { communication; student's } \\ \text { aggressive } \\ \text { vocational student }\end{array}$

\section{How to cite (APA $7^{\text {th }}$ Edition)}

Yulina, E., Menanti, A., \& Hardjo, S. (2021). Predicting students' aggressive behavior by coping mechanisms and interpersonal communication. INSPIRA: Indonesian Journal of Psychological Research, 2(1), 34-40. https://doi.org/10.32505/inspira.v2i1.3079

This is an open-access article distributed under the Creative Commons Attribution License, which permits unrestricted use, distribution, and reproduction in any medium provided the original work is properly cited. This is enabled under the terms of attribution and noncommercial usage of the material (C2021 by Eva Yulina, Asih Menanti, \& Suryani Hardjo. 


\section{INTRODUCTION}

Adolescence is often said to be a period of storms and stress, i.e., a time of high emotional tension caused by physical and glandular changes (Hurlock, 1991). This age of youth experiences instability over time because they are in a transition period, and they are trying to adopt new behaviors from previous phases of development. Santrock (2007) describes the turmoil caused both by the social function of adolescents in preparing for maturity (seeking self-identity and establishing their position in society), by physical growth (the development of secondary sexual signs), the development of intelligence (sharp and critical reasoning), and emotional changes (more sensitive, quickly angry and aggressive).

Along with physical and psychic changes, adolescents begin to break away from parental bonds and then notice personality changes manifest in their way of life to fit in society (Gunarsa, 2004). Hurlock (1991) states that the social environment that gives rise to security and openness influences social relations. Adolescence is synonymous with the social environment in which they interact, making them required to adjust effectively. When the activities are undertaken are inadequate to meet the demands of energy turmoil, they often overflow their excess energy negatively, one of which is aggressive behavior.

Aggressive behavior leads to the success of hurting or injuring living things that do not want to be treated as such (Baron \& Byrne, 2005). MacNeil \& Stewart (2000) says that aggressive behavior is a behavior or an act intended to dominate or behave destructively, through verbal force or physical force, directed at the object of aggressive behavior. The object of aggressive behavior targets includes the physical environment, others, and yourself.

Aggressive behavior is an act that is done to hurt or injure a person, which is an outpouring of emotion in reaction to the failure of the individual displayed in the destruction of humans or objects with elements of intentionality expressed by words (verbal) and behavior (nonverbal). Adolescents' aggressive behavior relates to periods of adolescent development that often conflict in the search for self-identity (Papalia, Olds \& Feldman, 2009). Khamsita's research (2007) stated that the frustration factor is related to aggressive behavior, where the higher the frustration of adolescents, the higher the aggressive behavior. Restu, Yusri \& Ardi's study (2013) also stated that aggressive behaviors by adolescents in school, namely physical and verbally aggressive behavior and aggressive behavior, are caused by frustration, power, temperature, and provocation. In the study respondents, adolescent aggressive behavior is to argue if you disagree, angry, threatening, damaging goods/objects, feel envious, suspicious, hit friends, taunt, hostility, and fight if they feel harassed.

According to Ajzen (2005), aggressive behavior arises beginning with the intention or desire to commit such aggressiveness, which if the intention is reinforced by factors that can trigger, then there will be aggressive behavior. Conversely, if the intention is not supported, it will be less likely to the occurrence of such aggressive behavior.

Aggressiveness is a motive that is present in the life of everyone. The students encourage this behavior due to the low coping mechanisms in adolescents and poor interpersonal communication that makes students tend to engage in such aggressive behavior.

Coping is a mechanism to address the changes faced or the burdens received. Keliat (1999) suggests coping mechanisms are how individuals solve problems, adjust to changes, and respond to threatening situations. The individual will become aggressive if the coping mechanism does 
not function properly and will experience disruption in his social adjustments. As a result, the individual cannot control his behavior, resulting in aggressive behavior. Therefore, this coping mechanism has an important role in the development of children.

In addition, adolescence is when they begin to leave childhood dependent on parents by searching for self-identity to answer who they are and find their place in this world. In search of self-identity or identity, individuals will assess and mimic adult behavior while being aware of what adults expect. The first model that individuals imitate is from their own family, i.e., parents. Family is the first environment that will determine the behavior of adolescents and schools where children spend much time in school. In addition to being at home in school, teenagers also interact a lot socially with friends and educators.

Coping mechanisms in solving problems differ from one to another, and some are adaptive and maladaptive. Coping mechanisms in an adaptive way will suppress negative behavior, while negative maladaptive means will increase the risk of aggressive behavior. According to Mundy (in Guswani and Kawuryan, 2011), the appearance of aggressive behavior can be caused by individuals dealing with unpleasant situations in their environment. Rahayu (in Guswani and Kawuryan, 2011) said that several factors, verbal aggressiveness, influence individuals who engage in aggressive behavior. Individuals whose interpersonal communication is poor can more easily appear aggressive behavior than those with good interpersonal communication.

All the maladaptive coping mechanisms used will not solve the difficulties properly but rather add difficulties and conflicts, tensions, fears, and anxieties that can eventually lead to aggressive behavior (Kartono, 2011).

Communication is an important skill in human life, both verbally and nonverbally. Interpersonal communication is a process of exchanging meaning between people who communicate with each other. The purpose of this process is to refer to changes and actions that take place continuously. Students in their socialization at school have conducted interpersonal communication with the social environment in the school. Interpersonal communication occurs in students regardless of various influences, such as residence, family, school and peers, and activities they do in daily life. Often students whose interpersonal communication is poor resulted in themselves being less able to control their aggressive behavior.

The tendency of students to engage in aggressive behavior-when experiencing poor interpersonal communication and changes in coping mechanisms-was caused by the words of parents, teachers, and peers and situations in the school environment. However, it seems that not all students can express aggressive behavior. Some of them do such aggressive behavior verbally (shouting) and nonverbal (hitting, throwing, fighting).

Several studies related to coping mechanisms, interpersonal communication, and aggressive behavior have been conducted several times. Mulyadi \& Hidayat (2014) researched the relationship between individual coping mechanisms and interpersonal communication anxiety. Later in another study, Radhiah, Nauli, \& Arneliwati (2011) showed a link between adolescents' coping mechanisms and aggressive behavior. The higher the coping mechanism, the lower the aggression behavior. On the contrary, the lower the coping mechanism, the higher the aggression behavior. However, studies that use various coping mechanisms and interpersonal communication as predictors of aggressive behavior have never been conducted. Thus, the 
current research aims to identify coping mechanisms and interpersonal communication with aggressive behavior in students.

\section{RESEARCH METHOD}

This research was conducted with a quantitative approach with an associative design involving 93 students of the Department of Automotive SMK Swasta PAB 12 Saentis selected by using Sample Random Side. The scale of the coping mechanism of students is based on the theory put forward by Keliat (1991) with three dimensions: focusing on problems, focusing cognitively, focusing on emotions. The scale consists of 10 indicators with 19 favorable items and 19 unfavorable items.

The scale of students' interpersonal communication is based on the theory put forward by Keliat (1991); there are five dimensions: openness, empathy, supportiveness, positiveness, equality, consisting of 20 favorable items and 20 unfavorable items. Meanwhile, the Aggressive Behavior Scale is based on the theory put forward by Schneiders (2005), which are seven aspects: aggressive verbal behavior, physically aggressive behavior, aggressive instrumental behavior, direct aggressive behavior, indirect aggressive behavior, emotionally aggressive behavior, aggressive group behavior. The researchers compiled the scale of this aggressive behavior, consisting of 34 items divided into 17 favorable and 17 unfavorable items.

The data analysis method used is multiple regression analysis that analyzes the relationship between two or more variables with the application-assisted Statistical Product and Service Solution (SPSS) for Windows version 20.

\section{RESULT}

Based on normality tests, the student's aggressive behavior variables, coping mechanisms, and interpersonal communication support spread following the normal spread. As a criterion, if $\mathrm{p}>0.050$, then it is declared normal and vice versa when $\mathrm{p}<0.050$, the spread is declared abnormal. Table 1 below is a summary of the results of the spread normality test calculation.

Table 1 Normality Test

\begin{tabular}{cccc}
\hline Variable & Kolmogorov-Smirnov & p-value & Explanation \\
\hline Aggresiveness & 1,494 & 0,053 & Normal \\
\hline Coping mechanism & 2,013 & 0,071 & Normal \\
\hline $\begin{array}{c}\text { Interpersonal } \\
\text { communication }\end{array}$ & 1,747 & 0,123 & Normal \\
\hline
\end{tabular}

The results of the linearity test showed that the variables of coping mechanisms and interpersonal communication had a linear relationship to the students' aggressive behavior variables. As a criterion, if $\mathrm{p}<0.05$, then it is declared to have a linear degree of relationship.

Table 2 Correlation Test

\begin{tabular}{cccc}
\hline Correlation & F & p-value & Explanation \\
\hline $\mathrm{X} 1-\mathrm{Y}$ & 283,424 & $<0,001$ & Linear \\
\hline $\mathrm{X} 2-\mathrm{Y}$ & 68,306 & $<0,001$ & Linear \\
\hline
\end{tabular}

The results of the data analysis in this study showed that the coefficient $\left(\mathrm{R}^{2}\right)$ of the relationship between coping mechanisms and interpersonal communication with students' aggressive behavior was 0.472 . This result suggests that coping mechanism variables can form students' aggressive behavior variables, and interpersonal communication is $47.2 \%$. In 
comparison, $52.8 \%$ of other free variables correlate with students' aggressive behavior but are not yet found in this study.

Table 3 Correlation Coefficient

\begin{tabular}{ccccc}
\hline Variabel & $\mathbf{F}$ & $\mathbf{R}$ & $\mathbf{R}^{\mathbf{2}}$ & p-value \\
\hline $\mathrm{X} 1-\mathrm{Y}$ & - & $-0,547$ & 0,299 & $<0,001$ \\
\hline $\mathrm{X} 2-\mathrm{Y}$ & - & $-0,281$ & 0,079 & 0,007 \\
\hline $\mathrm{X} 1-\mathrm{X} 2-\mathrm{Y}$ & 40,265 & $-0,687$ & 0,472 & $<0,001$ \\
\hline
\end{tabular}

Then based on the analysis conducted using product moment, $\mathrm{rx}_{1} \mathrm{y}$ correlation coefficient value of -0.547 and $p<$ value of 0.05 , there is a significant negative relationship between students' coping mechanism and aggressive behavior. Then obtained $\mathrm{rx}_{2} \mathrm{y}$ correlation coefficient value of -0.281 and $\mathrm{p}$-value $<0.05$; then, there is a significant negative relationship of interpersonal communication with students' aggressive behavior.

\section{DISCUSSION}

The results showed that the partial correlation value of coping mechanism (X1) with aggressive behavior $(\mathrm{Y})$ was -0.547 , and the $\mathrm{p}<$ value of 0.05 meant there was a negative and significant relationship between coping mechanism and aggressive student behavior. The score indicates that the direction of the relationship of the two negative variables, meaning that the higher the coping mechanism score, the lower the student's aggressive behavior, the lower the coping mechanism of a person's student, the higher the student's aggressive behavior, thus the hypothesis proposed in this study is accepted.

A person with a high coping mechanism believes that they can do something to change the events around him, whereas a person with a common coping mechanism considers himself incapable of restraining his aggressive behavior and will explode towards the surroundings. In difficult situations, the common coping mechanism considers itself to be behaving aggressively and detrimental to others and succumbing to negative circumstances. In contrast, its high coping mechanism will try harder to overcome the challenges that exist to minimize the aggressive behavior caused.

The results of this study are in line with research conducted by Mulyadi \& Hidayat (2014). Based on the results of the study (descriptive and inferential statistical tests) can be concluded that there is a relationship of individual coping mechanisms with interpersonal communication anxiety in nursing students at Universitas Wiraraja, most respondents have adaptive coping mechanisms, and most respondents experience interpersonal communication with the category of mild anxiety. Similarly, in research conducted by Radhiah, Nauli, \& Arneliwati (2010), there is a negative relationship between maladaptive coping mechanisms and aggressive behavior, showing a relationship between coping mechanisms and aggressive behavior in adolescents. Based on statistical tests obtained, there is a significant, meaningful relationship between adolescents' coping mechanisms and aggressive behavior in SMK Negeri 2 Pekanbaru.

The results showed that the partial correlation value of interpersonal communication (X2) with aggressive behavior $(Y)$ of -0.281 with $\mathrm{p}<0.05$ means that there is a negative and significant correlation. The score indicates that the direction of the relationship of the two variables is negative, meaning that the higher the interpersonal communication, the lower the student's aggressive behavior. On the contrary, the lower the interpersonal communication, the higher the 
aggressive behavior of students, thus the hypothesis proposed in this study is accepted. This is in line with Minarni's research (2017) that shows a strong and negative correlation between parental interpersonal communication and aggressive behavior of gang members in Samarinda. The findings are also in accordance with Sarwono's opinion (in Taganing \& Fortuna, 2008), which says that parenting patterns strongly influence aggressive behaviors by students. Parents who demand their children to follow all their will frustrate the child so that when the child is outside the house will act aggressively.

The results obtained from the study showed that coping mechanisms and interpersonal communication have a significant negative relationship with aggressive behavior in social in private vocational school PAB 12 Saentis. This is indicated by the coefficient value $F_{\text {reg }}=40.265$ where $\mathrm{p}<0.05$. This indicates that coping mechanisms and interpersonal communication are significantly negatively related to students' aggressive behavior; the higher the value of coping mechanisms and aggressive behavior, the lower the aggressive behavior. On the contrary, the lower the value of coping mechanisms and social support, the higher the aggressive behavior. In addition, there are also research results that have been conducted showing the value of the determinant coefficient of 0.472 , which means that coping mechanism variables can form aggressive variables, and interpersonal communication is $47.2 \%$. At the same time, $52.8 \%$ of behaviors were influenced by other factors not studied in this study.

This is in line with the research that has been done by Ajzen (2005), aggressive behavior arises beginning with the desire to do such aggressiveness that if the desire is reinforced by factors that can trigger, then there will be aggressive behavior. Conversely, if the desire is not supportive, it will be less likely to occur such aggressive behavior. Wahyuningsih (2016) shows a relationship between interpersonal communication variables and coping strategies with stress in psychology students preparing a thesis. In other words, interpersonal communication and coping strategies have a relationship with stress in students putting together a thesis. The magnitude of the influence of interpersonal communication and coping strategies with student stress in compiling the thesis appears to be at an effective contribution of $37.3 \%$. This suggests that $62.7 \%$ of other factors affect student stress in putting together a thesis that was not revealed in the study.

\section{CONCLUSION}

This study indicates that the mechanism of coping and interpersonal communication is significantly negatively related to aggressive behavior; the higher the value of coping mechanism and interpersonal communication, the lower the aggressive behavior of students. Conversely, the lower the value of coping mechanisms and interpersonal communication support, the higher students' aggressive behavior. For the next researcher who wants to research coping, interpersonal communication, and aggressive behavior, especially vocational school students, to pay more attention to the ability of researchers and not to force themselves if the researchers can not run their research in the future. Use the latest reference sources and according to the conditions that occur in the field/research site. It is expected that in the future, researchers can further refine the results of the study by deepening the background of the problem, and the use of measuring instruments that correspond to the conditions in the field, then in the next study, can use more complex variables so that aggressive behavior can be understood comprehensively. 


\section{REFERENCES}

Ajzen, I. (2005). Attitudes, personality, and behavior. Open University Press

Baron, R. A. \& Byrne, D. (2005). Psikologi sosial. Erlangga.

Gunarsa, S. D. (2004). Psikologi praktis anak, remaja dan keluarga (7th ed). PT. Gunung Mulia

Guswani, A. M., \& Kawuryan, F. (2011). Perilaku agresi pada mahasiswa ditinjau dari kematangan emosi. Jurnal Psikologi Pitutur, 1(2), 86-92.

Hurlock, E. B. (1991). Psikologi perkembangan: Suatu pendekatan sepanjang rentang kehidupan. Erlangga

Kartono, K. (2011). Psikologi anak. Mandar Maju.

Keliat, B. A. (1999). Penatalaksanaan stres. Penerbit Buku Kedokteran: EGC.

Khamsita, W. E. (2007). Hubungan antara frustasi dengan perilaku agresif pada siswa (Studi pada siswasiswa SMK Al-Munawwarah Dumai Riau). [Undergraduate thesis, UIN Sultan Syarif Kasim Riau]

MacNeil, G. \& Steward, C. (2000). Crisis intervention with school violence problems and volatile situations. In A. R. Roberts (Ed.), Crisis intervention handbook: Assessment, treatment, and research (2nd ed., pp. 229-248). Oxford University Press.

Minarmi, S. (2017). Hubungan antara komunikasi interpersonal orang tua dengan perilaku agresif pada remaja anggota geng di Samarinda. [Undergraduate thesis, Universitas Mulawarman]

Mulyadi, E. \& Hidayat, S. (2014). Hubungan mekanisme koping individu dengan kecemasan komunikasi interpersonal pada mahasiswa ners. Jurnal Kesehatan "Wiraraja Medika", 4(2), 54-59.

Papalia, D. E., Olds, S. W., \& Feldman, R. D. (2009). Human development. Perkembangan manusia. Salemba Humanika

Radhiah, M., Nauli, F. A., \& Arneliwati, A. (2010). Hubungan mekanisme koping dengan perilaku agresif remaja. [Undergraduate thesis, Universitas Riau]

Restu, Y., Yusri, Y., \& Ardi, Z. (2013). Studi tentang perilaku agresif siswa di sekolah. Konselor, 2(1), 243-249.

Santrock, J. W. (2007). Perkembangan anak (1st ed). Erlangga.

Schneider, K. M. (2005). Aggression and cardiovascular response in children. Journal of Pediatric Psychology, 27(2), 565-573.

Taganing, N. M. \& Fortuna, F. (2008). Hubungan pola asub otoriter dengan perilaku agresif pada remaja. [Undergraduate thesis, Universitas Gunadarma]

Wahyuningsih .S. (2016). Hubungan komunikasi interpersonal dan strategi coping dengan stres pada mahasiswa. Psikoborneo: Jurnal Ilmiah Psikologi, 4(3). 376-382. 